\title{
Factors affecting the concentration and flux of materials in two southern Everglades mangrove wetlands
}

\author{
Stephen E. Davis III ${ }^{1,4, *}$, Daniel L. Childers ${ }^{1}$, John W. Day Jr. ${ }^{2}$, David T. Rudnick ${ }^{3}$, \\ Fred H. Sklar ${ }^{3}$ \\ ${ }^{1}$ Department of Biological Science/Southeast Environmental Research Center, Florida International University, University \\ Park Campus, Miami, Florida 33199, USA \\ ${ }^{2}$ Coastal Ecology Institute, Center for Coastal, Energy, and Environmental Resources, \\ Louisiana State University, Baton Rouge, Louisiana 70803, USA \\ ${ }^{3}$ Everglades Systems Research Division, South Florida Water Management District, \\ 3301 Gun Club Rd., West Palm Beach, Florida 33416, USA \\ ${ }^{4}$ Present address: Dept. of Wildlife \& Fisheries Sciences, Texas A\&M University, College Station, Texas 77843-2258, USA
}

\begin{abstract}
Concentrations and fluxes of $\mathrm{C}, \mathrm{N}$, and $\mathrm{P}$ were measured in dwarf and fringe mangrove wetlands along the Taylor River, Florida, USA from 1996 to 1998. Data from these studies revealed considerable spatial and temporal variability. Concentrations of $\mathrm{C}, \mathrm{N}$, and $\mathrm{P}$ in the dwarf wetland showed seasonal trends, while water source was better at explaining concentrations in the fringe wetland. The total and dissolved organic carbon (TOC and DOC), total nitrogen (TN), and total phosphorus (TP) content of both wetlands was higher during the wet season or when water was flowing to the south (Everglades source). Concentrations of nitrate plus nitrite $\left(\mathrm{NO}_{\mathrm{x}}^{-}\right)$, ammonium $\left(\mathrm{NH}_{4}{ }^{+}\right)$, and soluble reactive phosphorus (SRP) in the fringe wetland were all highest during the dry season or northerly flow (bay source). Nutrient concentrations most effectively explained patterns of flux in both wetlands. Increased wetland uptake of a given constituent was usually a function of its availability in the water column. However, the release of $\mathrm{NO}_{\mathrm{x}}{ }^{-}$from the dwarf wetland was related to the $\mathrm{NH}_{4}{ }^{+}$concentration, suggesting a nitrification signal. Nitrogen flux in the dwarf wetland was also related to surface water salinity and temperature. Our findings indicate that freshwater Everglades marshes are an important source of dissolved organic matter to these wetlands, while Florida Bay may be a source of dissolved inorganic nutrients. Our data also suggest that temperature, salinity, and nutrient concentrations (as driven by season and water source) influence patterns of materials flux in this mangrove wetland. Applying long-term water quality data to the relationships we extracted from these flux data, we estimated that TN and TP were imported by the dwarf wetland $87 \pm 10$ and $48 \pm 17 \%$ of the year, respectively. With Everglades restoration, modifications in freshwater delivery may have considerable effects on the exchanges of nutrients and organic matter in these transitional mangrove wetlands.
\end{abstract}

KEY WORDS: Wetland-water column fluxes - Nutrient concentrations - Salinity - Temperature · Water source $\cdot$ Season

Resale or republication not permitted without written consent of the publisher

\section{INTRODUCTION}

Studies of materials exchange in tidal mangrove wetlands are becoming more prevalent in the estuarine literature. As a result, we are gaining a better understanding of the environmental factors that regulate the exchanges of mangrove-derived matter in these tropical and subtropical estuarine systems. More than $20 \mathrm{yr}$ ago, it was suggested that local hydrologic and geomorphologic factors largely governed the flux of organic matter in estuarine wetlands (Odum et al. 1979). This was later supported by evidence from outwelling studies, demonstrating that mangrove wetlands exported organic matter in relation to tidal 
energy (Twilley 1985; review by Lee 1995). While studies such as these have revealed the importance of tide to the fate and transport of organic matter (i.e. carbon), little work has been done to further our understanding of exchanges of ecologically important nutrients such as nitrogen and phosphorus, especially in micro- to non-tidal, seasonally flushed mangrove systems. For the most part, the ecological role of these types of mangrove systems has been overlooked.

Nitrogen and phosphorus may enter mangrove systems via a number of different pathways (Boto 1982, Liebezeit 1985). Of these, precipitation, upland runoff, and tides are among the most important. In many mangrove wetlands, these sources of inorganic and organic nutrients are often intermittent as a function of seasonal transition, producing intra-annual patterns of nutrient concentrations and, sometimes, flux (Twilley 1985, Rivera-Monroy et al. 1995, Ohowa et al. 1997). Furthermore, in some non-mangrove estuarine systems, the direction and magnitude of nutrient flux has been shown to correspond to nutrient concentrations in the water column (Wolaver \& Spurrier 1988, Whiting et al. 1989, Childers et al. 1993). Given that, an understanding of the factors that regulate nutrient concentrations in mangrove wetlands may also yield valuable insights into how these estuarine systems transform and exchange materials.

Water temperature and salinity are 2 of the most important factors controlling the global and local distributions of mangrove ecosystems along the world's shorelines (Kuenzler 1974, Odum et al. 1982, McMillan \& Sherrod 1986, Duke 1992). This control is manifest in the influence of these factors on the zonation and productivity of various mangrove species (Lugo \& Snedaker 1974, Cintrón et al. 1978, Ball 1988, Clough 1992). In tropical and subtropical areas, water temperatures are generally a function of season or time of year, reflecting changes in air temperature and light intensity. Salinity is usually an indicator of a combination of season, water source, or physical position within an estuary. Fluctuations in either of these factors can have profound effects on forest and benthic productivity in mangrove wetlands (Alongi 1988, Alongi \& Sasekumar 1992, Clough 1992). Therefore, seasonal changes in salinity and temperature may affect the availability, uptake, or release of a given constituent in a mangrove wetland. Relationships of this type have already been documented in temperate salt-marsh systems. For instance, investigators at North Inlet, South Carolina, USA, found increased phosphorus uptake by a Spartina marsh at higher salinities and water temperatures (Wolaver \& Spurrier 1988). Although the direct effects of these parameters on phosphorus exchange were not tested, these types of relationships suggested testable hypotheses. Quantifying relation- ships such as these can also lead to a better understanding of nutrient dynamics in estuarine wetlands, aiding in the development of dynamic budgets or other system-level models that account for organic or inorganic materials.

In this synthesis, we sought to determine the relationships among various environmental parameters (chemical, physical, and hydrological) and nutrient dynamics in 2 southern Everglades mangrove forests. Specifically, we examined how factors such as season, water source, salinity, and temperature controlled the concentration and flux patterns of carbon, nitrogen, and phosphorus in dwarf and fringe mangrove wetlands of the Taylor River, Everglades National Park, observed by Davis et al. (2001a,b). Given the lack of a strong tidal signature and the contrasting seasonal hydrology of the southern Everglades mangrove zone (wet vs dry), we anticipated that each of these parameters would be helpful in explaining temporal patterns of concentrations and fluxes that we have observed in these wetlands.

The Taylor Slough region of Everglades National Park is currently undergoing hydrologic restoration in the form of a systematic, long-term increase in freshwater delivery. Therefore, an understanding of the relationship between the concentration and flux of materials, as well as the factors that govern water quality signatures, is needed in order to assess the longterm effects of restoration on the southern Everglades mangrove zone and adjacent Florida Bay estuary. Addressing this need, we sought to use long-term water quality data collected near each site to make predictions of nutrient flux based on the relationships we found in this synthesis.

\section{MATERIALS AND METHODS}

Site description. From August 1996 to August 1998, we conducted quarterly studies of mangrove watercolumn nutrient exchange in dwarf and fringe wetlands along the Taylor River, Everglades National Park (Fig. 1; Davis et al. 2001a,b). Both wetlands were dominated by Rhizophora mangle L., with a stunted $(<1.5 \mathrm{~m})$, low productivity form at the dwarf sites and a taller $(<10 \mathrm{~m})$, more productive form at the fringe sites (Coronado-Molina 2000). A non-tidal dwarf mangrove site was located in an area of the Taylor River where water levels and current velocities tend to be low $(<0.5$ and $<0.01 \mathrm{~m} \mathrm{~s}^{-1}$, respectively). On the other hand, the fringe mangrove site was established along the vegetated banks of the lower Taylor River where depths can exceed $2 \mathrm{~m}$ and current velocities range from 0 to $>0.5 \mathrm{~m} \mathrm{~s}^{-1}$ (see Davis et al. 2001a,b for detailed site descriptions). 
The lower Taylor River is micro-tidal with a tidal range of $<0.05 \mathrm{~m}$. Therefore, the movement of water, salt, and materials throughout this system is determined mainly by the interactions of direct precipitation, upland runoff, and wind. Generally speaking, low salinity ( 0 to $10 \%$ ) predominates throughout the Taylor River for much of the wet season (June to November). However, as the dry season (December to May) progresses, salinity can often exceed $30 \%$, reflecting salinity patterns in Little Madeira Bay (Fig. 1). Given its proximity to the creek mouth, the fringe mangrove wetland typically has a higher mean salinity than the dwarf wetland, and responds more rapidly to increases in salinity during the dry season. Alternatively, the dwarf wetland typically has a lower mean salinity, exhibiting wet season decreases in salinity before the fringe site (Fig. 2).

Wet season sources of water, nutrients, and organic matter to these wetlands are primarily through precipitation and upland runoff from the freshwater Everglades marshes, whereas Florida Bay (via Little Madeira Bay) is a major source during the dry season. These different sources can have profound impacts on the salinity, organic, and inorganic nutrient content of the surface water in this area of the southern Everglades. In addition, during the transition from the wet season to the dry season, wind events associated with frontal passages can significantly affect salinity and water flux through the Taylor River (Sutula 1999). Water temperature in both wetlands is also variable throughout the year as a result of air temperature, light intensity, and precipitation.

Field and analytical methods. Eight quarterly samplings of mangrove island enclosures (Davis et al. 2001a) and in-channel flumes (Davis et al. 2001b) were made over 4 wet season and 4 dry season periods from August 1996 to August 1998 (Fig. 2). These techniques were used to determine wetland watercolumn exchanges of carbon, nitrogen and phosphorus at both mangrove sites. Additional water samples were also collected in these studies to determine ambient concentrations of each of the constituents of interest.

Portions of all water samples were filtered (Whatman $\mathrm{GF} / \mathrm{F}$ ) and analyzed for soluble reactive phosphorus (SRP), ammonium $\left(\mathrm{NH}_{4}^{+}\right)$, and nitrate plus nitrite $\left(\mathrm{NO}_{\mathrm{x}}{ }^{-}\right)$on a 4-channel auto-analyzer (Alpkem model

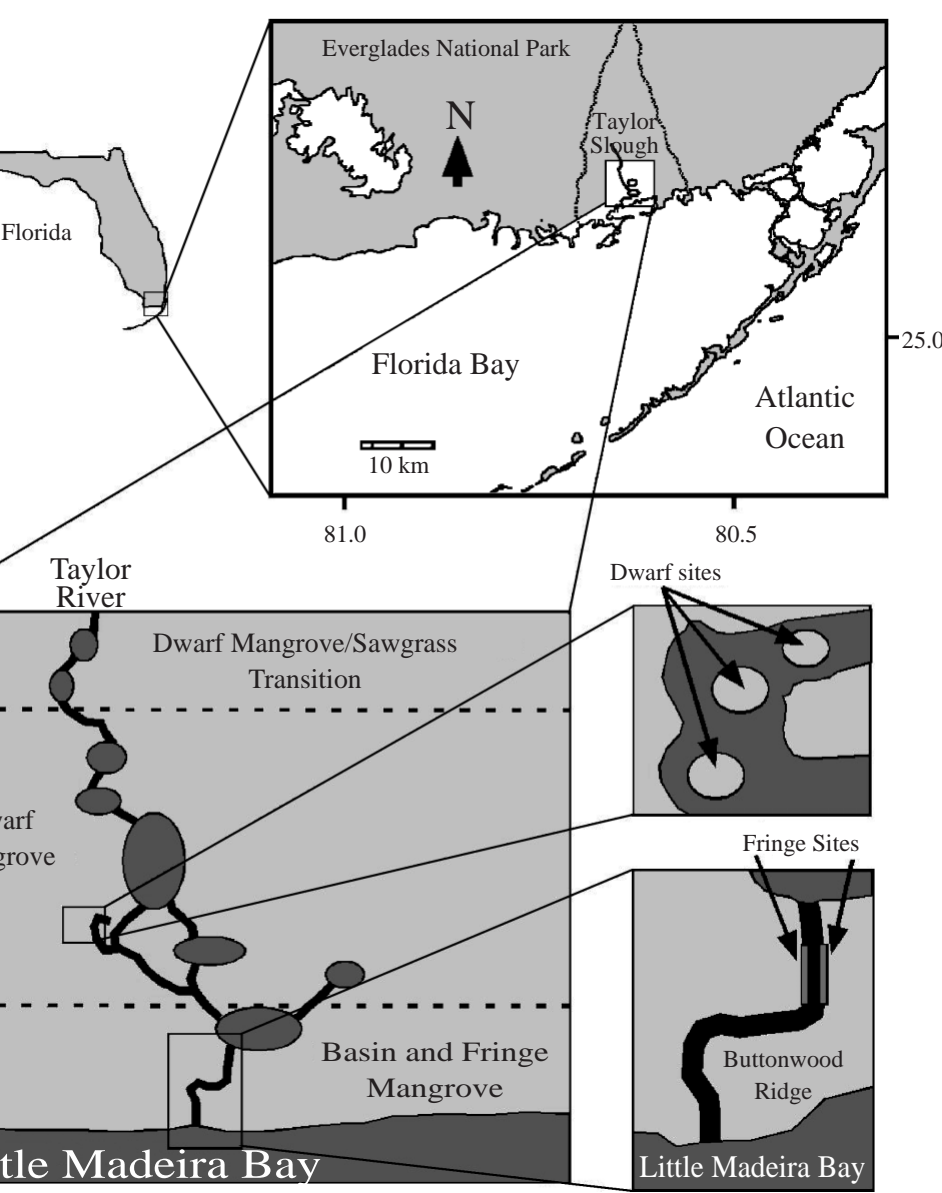

Fig. 1. The southern Everglades region of Everglades National Park (upper right) is shown relative to the state of Florida (upper left). The enlarged area of the Taylor Slough (bottom left) highlights the Taylor River and the transition of mangrove communities from the freshwater end of the estuarine mangrove wetlands are indicated and illustrated in the lower right corner. In these illustrations, the dark shaded areas represent shallow ponds, light shaded areas represent mangrove forest, and thick black lines represent the channel of the Taylor River
RFA 300). These samples were also analyzed for dissolved organic carbon (DOC) using a hot platinum catalyst, direct injection analyzer (Shimadzu model TOC-5000). Unfiltered water samples were analyzed for total phosphorus (TP) using the dry ashing, acidhydrolysis technique (Solorzano \& Sharp 1980); for total nitrogen (TN) using an Antec $7000 \mathrm{~N}$ total nitrogen analyzer; and for total organic carbon (TOC) using the same method listed above for DOC.

For each flux method (enclosure or flume), sampling was conducted at hourly intervals for approximately $6 \mathrm{~h}$ and repeated on consecutive days. Measurements of salinity, water temperature, and current (speed and direction) were taken at the same hourly intervals (Davis et al. 2001a,b). Calculated net areal fluxes indi- 


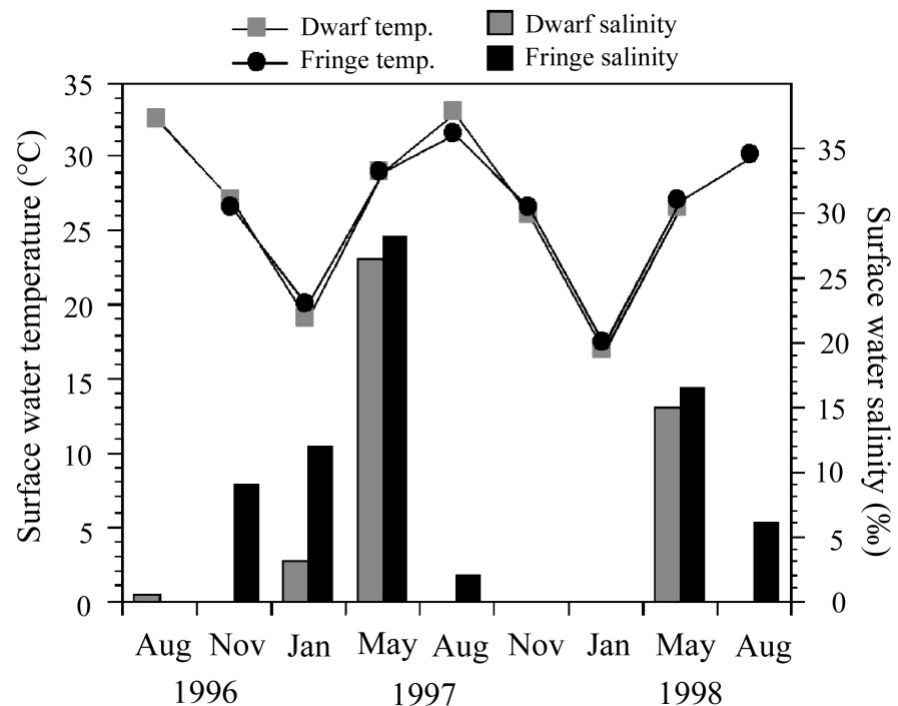

Fig. 2. Plot of mean surface water temperature and salinity during each sampling of the dwarf (light) and fringe (dark) mangrove sites along the Taylor River. In South Florida, August and November are typically wet season months and January and November are dry season months

cated release from the wetland (negative flux), uptake by the wetland (positive flux), or no net flux.

Statistical analyses. We utilized a number of simple statistical procedures to determine relationships between the various chemical and physical components measured in these mangrove wetlands. An alpha level of 0.05 was used to determine significance for each statistical procedure. In order to discern the relationships among the various water quality parameters, we generated a correlation matrix of temperature, salinity, and constituent concentrations for each site. Using Fisher's r to z transformation, we were able to generate $\mathrm{p}$-values and distinguish significant correlations. Next, we used 1-factor ANOVA tests to determine significant season effects (wet vs dry) on the concentration and flux of each constituent at both sites. These same procedures were also used to test for the effect of water source (as direction of flow; north vs south) on concentration and flux at the fringe site. Direction of flow or water source was not considered at the dwarf site, where current was rarely detectable. For each significant ANOVA, we used Fisher's pairwise least significant differences tests (PLSD) to determine significant differences between treatment means.

Finally, we used temperature, salinity, and concentrations as independent variables in various regression analyses to explore the relationships between these variables and wetland water-column fluxes in each wetland. For all significant flux regressions, we calculated an import/export switch (after Childers et al. 1993) as a prediction of the point along the $x$-axis (temperature, salinity, or concentration) at which flux in either mangrove wetland shifted from import to export, or vice versa. We also generated $95 \%$ confidence intervals for each regression to set error bounds on our flux estimates.

Long-term water quality data. A fundamental goal of this analysis was to apply long-term water quality data to our statistical relationships in order to make predictions of nitrogen or phosphorus flux in dwarf and fringe mangrove wetlands of the Taylor River. Since 1996, we have been monitoring daily concentrations of salinity, TN, and TP in the Taylor River. Initially, we collected a single $1 \mathrm{l}$ sample of water each day near the mouth (fringe mangrove; from August 1996), and at the upstream end of the river (dwarf mangrove; from May 1998). These samples were a mixture of $4 \times 250 \mathrm{ml}$ subsamples collected every $6 \mathrm{~h}$. This protocol was later changed, in October 1998, to 4 $\times 250 \mathrm{ml}$ sub-samples collected at $18 \mathrm{~h}$ intervals over a period of $3 \mathrm{~d}$. These intervals - 00:00 h Day 1, 18:00 h Day 1, 12:00 h Day 2, and 06:00 h Day 3represent the full range of light and temperature conditions exhibited throughout the day, yet integrate water quality over a period of $3 \mathrm{~d}$. Therefore, we used the integrated concentrations for each parameter (salinity, [TN], and [TP]) as the mean concentration for each day of the $3 \mathrm{~d}$ interval. For each significant regression relationship involving TN flux or TP flux, we used these monitoring data as independent variables to estimate daily fluxes in either wetland. In order to maintain continuity in our predictions of flux, we selected a common timeframe of water quality data for both sites (June 1998 to December 1999).

Table 1. Matrix showing significant $(\mathrm{p}<0.05)$ correlations between various water quality parameters ( $\mathrm{n}=180$ for each) measured at the dwarf mangrove site of the Taylor River, Everglades National Park (Sal. = surface water salinity; Temp. = surface water temperature $; \mathrm{SRP}=$ soluble reactive phosphorus; $\mathrm{TP}=$ total phosphorus; $\mathrm{TOC}=$ total organic carbon; $\mathrm{DOC}=$ dissolved organic carbon; $\mathrm{TN}=$ total nitrogen)

\begin{tabular}{|lrrrrrrrr|}
\hline & Sal. & Temp. & {$\left[\mathrm{NO}_{\mathrm{x}}{ }^{-}\right]$} & {$\left[\mathrm{NH}_{4}{ }^{+}\right]$} & {$[\mathrm{SRP}]$} & {$[\mathrm{TP}]$} & {$[\mathrm{TOC}]$} & {$[\mathrm{DOC}]$} \\
\hline Temp. & & & & & & & & \\
$\left(\mathrm{NO}_{\mathrm{x}}^{-}{ }^{+}\right.$ & & -0.573 & & & & & & \\
$\left(\mathrm{NH}_{4}{ }^{+}\right)$ & -0.606 & -0.631 & 0.588 & & & & & \\
$(\mathrm{SRP})$ & 0.377 & & & -0.427 & & & & \\
$(\mathrm{TP})$ & 0.436 & & -0.477 & -0.549 & 0.916 & & & \\
$(\mathrm{TOC})$ & -0.383 & 0.631 & & & & -0.445 & & \\
$(\mathrm{DOC})$ & & 0.504 & & & -0.413 & -0.581 & 0.916 & \\
$(\mathrm{TN})$ & -0.477 & 0.430 & & & & & 0.826 & 0.634 \\
\hline
\end{tabular}




\section{RESULTS}

Mean surface water temperature at both sites was essentially the same during each sampling (Fig. 2). However, mean salinity was consistently lower at the dwarf site, especially when riverwide salinity reached mesohaline levels (Fig. 2). The direction of flow at our fringe mangrove site varied within and between samplings, reflecting the influence of rapid changes in wind speed and direction and seasonal variability in upland runoff from freshwater Everglades marshes. As a result, southerly flow (upland influence) was not always observed during wet season samplings. Similarly, northerly flow (bay influence) was not always observed during dry season samplings. The shifting of flow, independent of season, that we observed allowed us to differentiate these as separate factors controlling the concentration and flux of materials in the fringe mangrove wetland.

\section{Correlation results (temperature, salinity, and $\mathrm{C}, \mathrm{N}$, and $P$ concentrations)}

We found a number of significant correlations among the various parameters measured in the water column of these mangrove wetlands. In many cases, the dwarf and fringe wetlands exhibited the same kinds of relationships. For example, [TOC], [DOC], and [TN] were all strongly and positively correlated with one another in both wetlands (Tables 1 \& 2). Similarly, both dissolved inorganic nitrogen (DIN) constituents were positively correlated with each other (Tables $1 \& 2$ ). [DIN] was negatively correlated with temperature, while [TOC], [DOC], and [TN] were all positively correlated with temperature in both wetlands (Tables 1 \& 2). [TOC] was negatively related to salinity in the dwarf and fringe wetlands, and [TP] was positively related to salinity in each. [TP] also correlated negatively with $\left[\mathrm{NO}_{\mathrm{x}}^{-}\right]$and $\left[\mathrm{NH}_{4}{ }^{+}\right]$in both sites (Tables 1 \& 2). [DIN] showed no positive correlation with $\mathrm{TN}$ at either site, reflecting the low inorganic content of the TN fraction (Davis et al. 2001a,b).

Differences between our Taylor River sites were also revealed in this correlation matrix analysis. These differences were mainly attributed to one or both phosphorus constituents (TP or SRP). [TP] in the dwarf wetland was negatively correlated with [TOC] and [DOC], while [SRP] was only negatively related to [DOC] in this wetland (Table 1). Dwarf mangrove [TP] and [SRP] also had a strong, positive correlation with each other even though SRP is typically less than $25 \%$ of the TP fraction. Both [TP] and [SRP] in the dwarf mangrove wetland were positively correlated with salinity (Table 1). These relationships were not observed in the fringe wetland. In fact, [SRP] did not correlate with any other parameter measured in the fringe mangrove. However, fringe [TP] was positively correlated with temperature (Table 2). There was also a clear, negative correlation between DIN and the organic content of the water at the fringe mangrove site, a characteristic not observed at the dwarf mangrove site (Tables $1 \& 2$ ).

\section{ANOVA results (concentrations and fluxes of C, N, and P)}

Analysis of variance was used to determine the effect of season and water source on nutrient concentration and flux at the 2 mangrove sites of the Taylor River. In the dwarf wetland, season appeared to only affect the organic content of the surface water, as [TOC], [DOC], and [TN] showed significant differences between the wet and dry season samplings in this wetland. In each case, concentrations of these constituents were all significantly higher during the wet season (Fig. 3). Fluxes in the dwarf wetland also appeared to be affected by differences between the wet season and dry season. Fluxes of $\mathrm{NO}_{\mathrm{x}}^{-}$measured at the dwarf site were generally from the wetland to the water column (export; Davis et al. 2001a). However, our analyses indicated that exports were significantly greater during the dry season (Fig. 4). Fluxes of TP also showed a weak season effect, with more TP uptake occurring during the dry season samplings (Fig. 4).

Neither season nor the direction of flow explained flux variability in the more lotic, fringe wetland. Only concentrations revealed any effect of these 2 factors at this site. Furthermore, these factors indicated differences in the dynamics of inorganic and organic matter in the lower Taylor River. Ammonium concentrations were significantly greater and total phosphorus con- 
Season
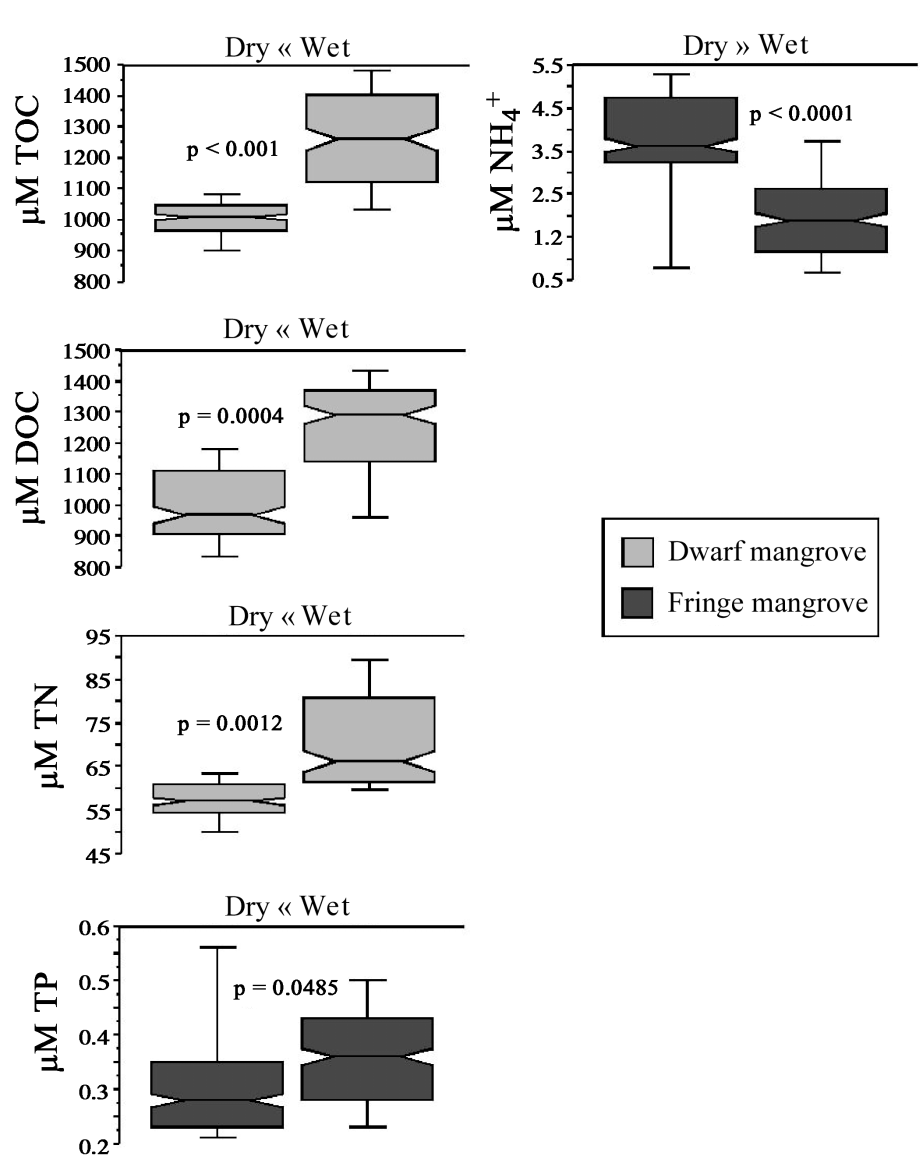

Dwarf mangrove
Direction of flow
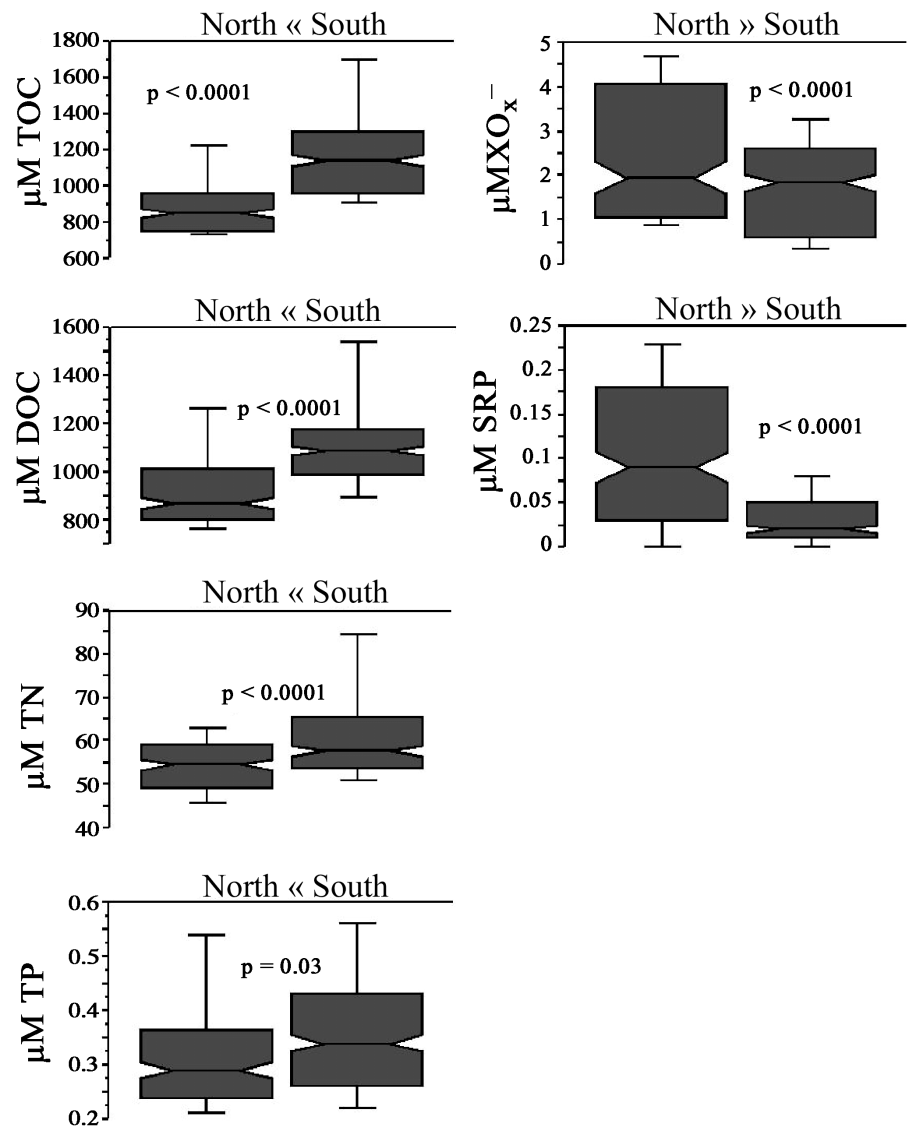

Fig. 3. Box-and-whisker plots of concentration distributions from the dwarf (light) and fringe (dark) mangrove sites showing significant $\left(\right.$ ANOVA $\left._{i} \mathrm{p}<0.05\right)$ effects of season and direction of flow. Post-hoc results (Fisher's pairwise least significant differences tests, PLSD) are indicated at the top of each plot. The middle line of each plot is the median of the distribution. The notches represent the $95 \%$ CI about the median. The bottom and top lines of each box are the 25th and 75th percentiles and the bottom and top lines of the whiskers indicate the 10 th and 90 th percentiles, respectively
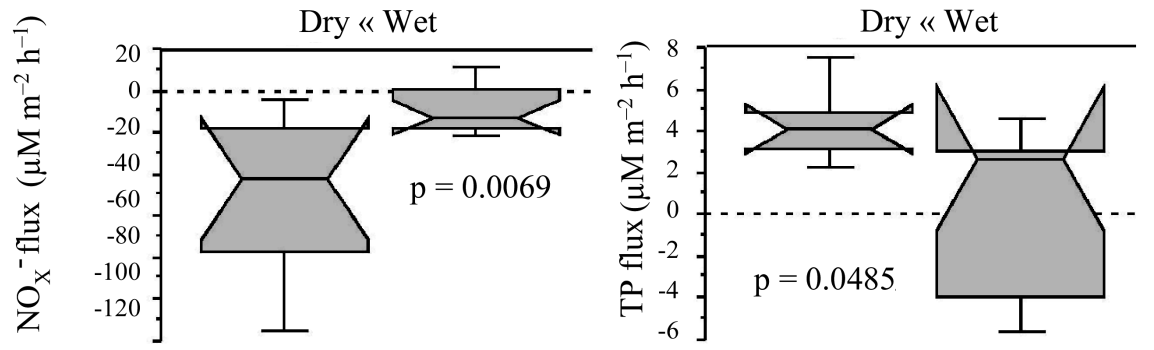

Fig. 4. Box-and-whisker plots of flux distributions from the dwarf mangrove sites showing significant (ANOVA; $p<0.05$ ) effects of season. Post-hoc results (Fisher's pairwise least significant differences tests, PLSD) are indicated at the top of each plot. The middle line of each plot is the median of the distribution. The notches represent the $95 \%$ CI about the median. The bottom and top lines of each box are the 25th and 75th percentiles and the bottom and top lines of the whiskers indicate the 10th and 90th percentiles, respectively. Anything above the zero line (positive) indicates uptake by the wetland, and anything below the zero line (negative) indicates release from the wetland centrations were significantly lower during the dry season samplings in the fringe mangrove wetland (Fig. 3). The $\mathrm{NO}_{\mathrm{x}}{ }^{-}$and SRP content of the water in this wetland was significantly higher when water was flowing from Florida Bay into the mangrove zone (northerly flow; Fig. 3). On the other hand, most other constituents, including TN, TP, TOC, and DOC, had concentrations that were significantly higher during periods of southerly flow (Fig. 3).

\section{Regression results (fluxes)}

We found a number of significant regressions that suggested a relation- 
ship between one of the independent variables we considered and nutrient flux (see Fig. 5 for examples of flux relationships observed in each mangrove wetland). However, many of these regressions yielded low $\mathrm{r}^{2}$ values $(<0.4)$, resulting in relatively weak predictive power (Table 3).

Of the relationships we found, most involved a nitrogen species and were limited to the dwarf mangrove wetland (Table 3). Total nitrogen flux in the dwarf wetland showed a negative linear relationship with salinity, with a predicted import/export (I/E) switch at around $27 \%$ (Table 3). Ammonium flux at the same site exhibited similar associations with salinity and temperature, shifting between import and export at approximately $13 \%$ and $31^{\circ} \mathrm{C}$, respectively (Table 3). On the other hand, flux of $\mathrm{NO}_{\mathrm{x}}{ }^{-}$at the dwarf site was positively related with temperature. However, the predicted I/E switch $\left(35^{\circ} \mathrm{C}\right)$ from this model was greater than any water temperature measured during these flux studies, and reflected the consistent export of $\mathrm{NO}_{\mathrm{x}}{ }^{-}$measured in this system (Davis et al. 2001a). Nitrate plus nitrite flux in the dwarf mangrove wetland also appeared to be controlled by the availability of $\mathrm{NH}_{4}{ }^{+}$in the water column, as $\mathrm{NO}_{\mathrm{x}}^{-}$import shifted to export at concentrations above $1.1 \mu \mathrm{M} \mathrm{NH}_{4}{ }^{+}$(Table 3). Total nitrogen flux in the dwarf mangrove exhibited a positive, linear relationship with its concentrations, as increased TN availability led to increased uptake by the wetland (Table 3). We found a similar, logarithmic relationship with TP flux in the dwarf wetland, with import occurring above $0.31 \mu \mathrm{M}$ TP (Table 3, Fig. 5).

In the fringe wetland, the fluxes of both DIN constituents were positively related to their respective concentrations (Table 3). This wetland showed a clear trend of DIN export when concentrations were low, then shifted to uptake at higher concentrations (Table 3; see $\mathrm{NO}_{\mathrm{x}}^{-}$flux graph in Fig. 5).
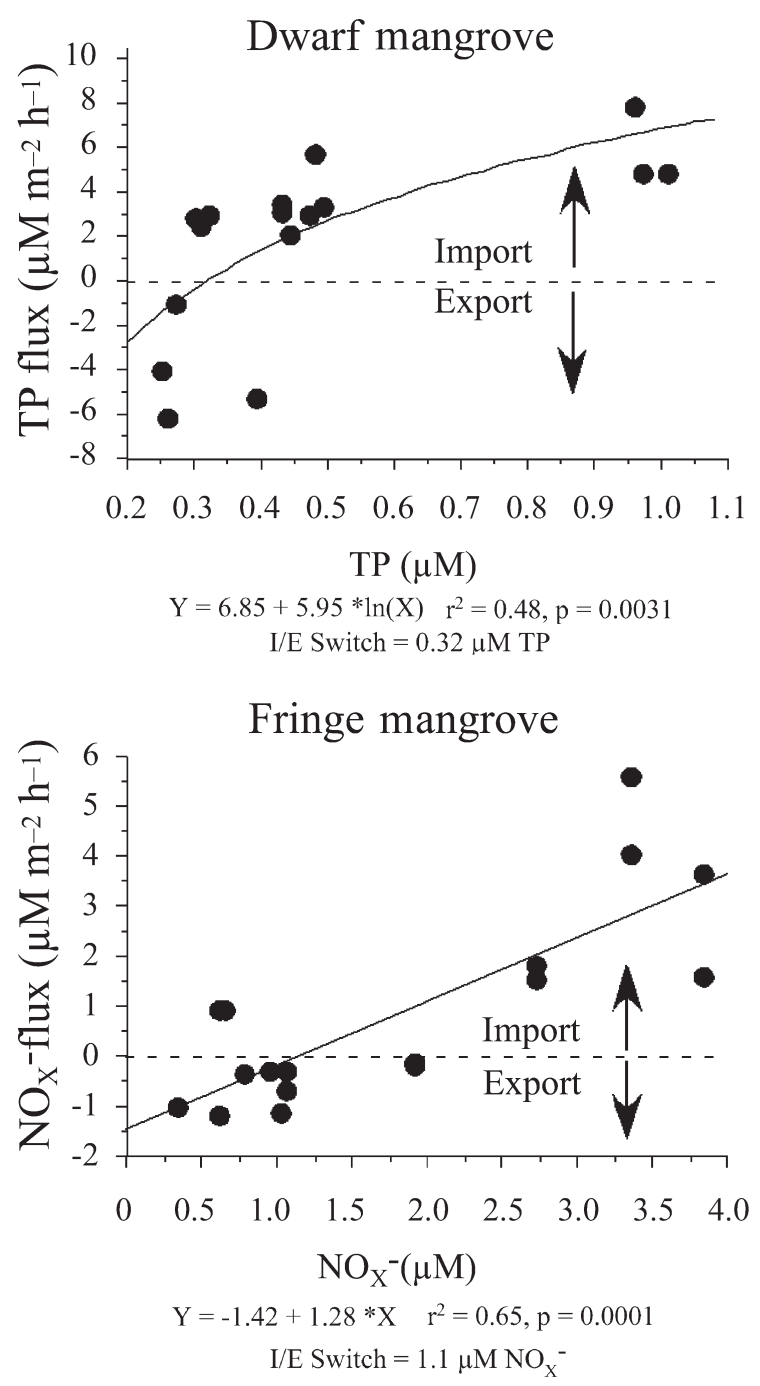

Fig. 5. Examples of regression plots and statistical output showing the relationship between concentrations and fluxes in dwarf and fringe mangrove wetlands along the Taylor River. The point where the predicted line crosses the zero line is the import/export (I/E) switch

Table 3. Significant regression models of nutrient flux vs salinity, temperature, and concentration in dwarf and fringe mangrove wetlands. The slope, $y$-intercept, and import/export (I/E) switch from each significant model are provided. Slopes and I/E switches for each are clarified

\begin{tabular}{|c|c|c|c|c|c|c|c|c|}
\hline Parameter & Factor & Wetland & $\mathrm{r}^{2}$ & $\mathrm{p}$-value & Slope & Intercept & I/E switch & Clarification \\
\hline $\mathrm{NH}_{4}{ }^{+}$flux & Salinity & Dwarf & 0.35 & 0.002 & -1.32 & 16.9 & $12.8 \%$ & Salinity $<\mathrm{I} / \mathrm{E} \approx \mathrm{NH}_{4}{ }^{+}$uptake \\
\hline TN flux & Salinity & Dwarf & 0.30 & 0.015 & -11.07 & 294.8 & $26.6 \%$ & Salinity $<\mathrm{I} / \mathrm{E} \approx \mathrm{TN}$ uptake \\
\hline $\mathrm{NO}_{\mathrm{x}}^{-}$flux & Temperature & Dwarf & 0.26 & 0.016 & 3.27 & -113.2 & $34.6^{\circ} \mathrm{C}$ & Temperature $>\mathrm{I} / \mathrm{E} \approx \mathrm{NO}_{\mathrm{x}}{ }^{-}$uptake \\
\hline $\mathrm{NH}_{4}^{+}$flux & Temperature & Dwarf & 0.36 & 0.002 & -2.28 & 69.6 & $30.6^{\circ} \mathrm{C}$ & Temperature $<\mathrm{I} / \mathrm{E} \approx \mathrm{NH}_{4}^{+}$uptake \\
\hline $\mathrm{NO}_{\mathrm{x}}^{-}$flux & {$\left[\mathrm{NH}_{4}^{+}\right]$} & Dwarf & 0.31 & 0.007 & -16.37 & 17.8 & $1.1 \mu \mathrm{M}$ & {$\left[\mathrm{NH}_{4}^{+}\right]>\mathrm{I} / \mathrm{E} \approx \mathrm{NO}_{\mathrm{x}}^{-}$release } \\
\hline TN flux & {$[\mathrm{TN}]$} & Dwarf & 0.35 & 0.008 & 9.04 & -330.1 & $36.5 \mu \mathrm{M}$ & {$[\mathrm{TN}]>\mathrm{I} / \mathrm{E} \approx \mathrm{TN}$ uptake } \\
\hline TP flux ${ }^{a}$ & [TP] & Dwarf & 0.48 & 0.003 & a & $\mathrm{a}$ & $0.31 \mu \mathrm{M}$ & {$[\mathrm{TP}]>\mathrm{I} / \mathrm{E} \approx \mathrm{TP}$ uptake } \\
\hline $\mathrm{NO}_{\mathrm{x}}^{-}$flux & {$\left[\mathrm{NO}_{\mathrm{x}}^{-}\right]$} & Fringe & 0.65 & 0.0001 & 1.28 & -1.4 & $1.1 \mu \mathrm{M}$ & {$\left[\mathrm{NO}_{\mathrm{x}}^{-}\right]>\mathrm{I} / \mathrm{E} \approx \mathrm{NO}_{\mathrm{x}}{ }^{-}$uptake } \\
\hline $\mathrm{NH}_{4}{ }^{+}$flux & {$\left[\mathrm{NH}_{4}^{+}\right]$} & Fringe & 0.71 & 0.001 & 1.06 & -3.7 & $3.5 \mu \mathrm{M}$ & {$\left[\mathrm{NH}_{4}^{+}\right]>\mathrm{I} / \mathrm{E} \approx \mathrm{NH}_{4}{ }^{+}$uptake } \\
\hline
\end{tabular}




\section{DISCUSSION}

We attempted to explain carbon, nitrogen, and phosphorus dynamics in 2 mangrove wetlands using a variety of factors including season, salinity, temperature, water source, and constituent concentrations. These factors were believed to be important since much of the southern Everglades mangrove zone is essentially nontidal, receives seasonal inputs from the freshwater Everglades (wet season) and Florida Bay (dry season), and is subject to frequent shifts in flow due to wind forcing. Past studies in an assortment of estuarine wetlands have used similar approaches to interpret observed temporal variations in concentration and flux data.

\section{Factors related to $\mathrm{C}, \mathrm{N}$, and $\mathrm{P}$ concentrations}

We found little effect of season on inorganic nutrient concentrations in the mangrove wetlands of the Taylor River, with only one constituent $\left(\mathrm{NH}_{4}{ }^{+}\right)$showing any effect of season. Similar observations have been made in coastal wetlands of the arid tropics, where daily concentration ranges for many inorganic nutrients are often as great as annual ranges (Guerrero et al. 1988, Ovalle et al. 1990). Mangrove systems with low terrestrial inputs also seem to lack significant seasonal variability in inorganic constituents (e.g. Coral Creek, Australia; Boto \& Wellington 1988). Still, season appears to be important in driving inorganic nutrient concentration patterns in other estuarine mangrove and salt marsh systems (Rivera- Wolaver et al. 1983, Wolaver et al. 1988, Wolaver \& Spurrier 1988, RiveraMonroy et al. 1995, Ohowa et al. 1997).

Water source was somewhat better at explaining inorganic nutrient concentrations at our fringe mangrove site. We found that both $\left[\mathrm{NO}_{\mathrm{x}}{ }^{-}\right]$and $[\mathrm{SRP}]$ at this site were higher during periods of northerly flow, suggesting the bay was a source of these nutrients (Fig. 3). Ovalle et al. (1990) observed similar patterns for DIN and SRP in a mangrove creek in Brazil. However, their findings were related to the direction of the tidal current rather than the persistent movement of water in a single direction, as is usually the case in the Taylor River. Due to the differences in hydrology between our sites, water source was only considered for the fringe mangrove. It is possible, however, that a factor as robust as this may explain more of the inorganic nutrient variability in the dwarf mangrove.

Season and water source were more powerful at explaining the variability in TOC, DOC, TN, and TP concentrations in the Taylor River mangrove wetlands, with significantly higher concentrations measured during the wet season or when water was flowing south (Fig. 3). Twilley (1985) and Rivera-Monroy et al. (1995) made similar observations in different mangrove wetlands for DOC and DON, respectively. At Bly Creek (South Carolina, USA), Wolaver et al. (1988) was able to relate high DON concentrations to freshwater inputs from a small blackwater stream. Particulate phosphorus (PP) concentrations in this same temperate salt marsh were highest in the summer months and correlated well with rainfall, among other factors (Wolaver \& Spurrier 1988). In contrast, Coral Creek, a system with little upland influence, exhibited no seasonal patterns for DOC, DON, or DOP (Boto \& Wellington 1988). These patterns - including our findings - illustrate the importance of both season and water source in governing temporal and spatial patterns of particulate and dissolved organic materials.

Salinity and water temperature can also be important in regulating water column concentrations of a number of different materials. In this analysis, both TOC (both sites) and TN (dwarf site only) were negatively related to salinity, reflecting the strong association of these constituents to a freshwater, upland source. Data from Twilley (1985) suggest a similar correlation between DOC and salinity at Rookery Bay, Florida. On the other hand, TP concentrations were positively related to salinity at both the Taylor River sites. This was not in agreement with the effects shown by [TP] for both season and water source (see Fig. 3), which suggested an upland source of this constituent. These confounding results are likely attributable to the subtle differences between the various factors considered in this analysis (i.e. salinity, season, and water source) as well as the weak season $(p=0.0485)$ and water source $(p=0.03)$ effects exhibited in TP concentrations.

Correlation analyses also allowed us to assess the relationships among the different parameters we measured such as TOC, DOC, and TN, which were all tightly coupled to one another (Tables 1 \& 2). Using a similar approach in Coral Creek, Boto \& Wellington (1988) found a lack of correlation among dissolved organic constituents (DOC, DON, and DOP) and concluded that DOM in their system was low in $\mathrm{N}$ and $\mathrm{P}$. Although the mean DOC concentration for Coral Creek ( 1.2 mM) was similar to the annual average for the Taylor River (1.1 $\mathrm{mM})$, total dissolved nitrogen in this tidal waterway $\left(T_{D N} \sim 4.5 \mu \mathrm{M}\right)$ was over an order of magnitude less than the Taylor River's TN concentrations $($ mean $=64 \mu \mathrm{M})$, the bulk of which was dissolved. In addition, molar ratios of $\mathrm{C}: \mathrm{N}$ in Coral Creek varied widely (18 to 35 ), as concentrations of $\mathrm{C}$ and $\mathrm{N}$ fluctuated independent of one another (Boto \& Wellington 1988). The mangrove wetlands along the Taylor River exhibited a much narrower annual range of C:N (16 to 19), again reflecting the common source of these materials (i.e. freshwater Everglades). The tight coupling of TOC, DOC, and TN also suggests that 
nitrogen may be an important component of DOM in southern Everglades mangrove wetlands. Recent geochemical evidence indicates that freshwater Everglades wetlands are sources of protein-rich organic material to overlying water, corroborating this notion (R. Jaffé unpubl. data).

\section{Factors related to the fluxes of organic and inorganic materials}

The export of organic matter in mangrove wetlands is a function of tidal energy (Twilley 1985, Lee 1995), yet this has only been rigorously tested in mangrove systems with strong tidal signatures. Odum et al. (1979) concluded that, as a result of south Florida seasons, estuarine wetlands in this region probably export particulate organic matter during the wet season and import it during the dry season. Such seasonal effects have been shown for particulate and organic nitrogen export in both tropical and temperate estuarine systems (Whiting et al. 1989, Rivera-Monroy et al. 1995). In our analysis, we found a relationship between season and flux for only 2 constituents ( $\mathrm{NO}_{\mathrm{x}}{ }^{-}$and $\mathrm{TP}$ ) at a single site (dwarf). As a result, our findings can neither support nor refute Odum et al.'s (1979) statement regarding seasonal fluxes.

We were able to explain some of the fluxes (especially $\mathrm{N}$ species) in the dwarf mangrove wetland using salinity and temperature. However, these variables alone did not account for all of the variability (note ${ }^{2}$ values in Table 3). The dwarf mangrove wetland consistently imported TN and $\mathrm{NH}_{4}{ }^{+}$(uptake; Davis et al. 2001a), yet regression analyses indicated a switch from import to export when salinity exceeded 12.8 and $26.6 \%$, respectively (Table 3 ). Similarly, uptake of $\mathrm{NH}_{4}{ }^{+}$in the dwarf wetland approached zero as water temperature increased to $\sim 31^{\circ} \mathrm{C}$ (Fig. 2). Davis et al. (2001a) found that $\mathrm{NH}_{4}{ }^{+}$export rarely occurs at this dwarf mangrove site, and data from this analysis suggests that these exports may be limited to the warmest days of the year.

In Chesapeake Bay, Boynton \& Kemp (1985) found that benthic fluxes of nitrate correlated well with salinity. In most cases, nitrate uptake increased with salinity at their sites (Boynton \& Kemp 1985). In Tomales Bay (California), Chambers et al. (1995) demonstrated that phosphorus release from suspended particulate matter increased relative to salinity. Although the initial $(8 \mathrm{~h})$ release was likely an abiotic process, longterm release ( 8 to $72 \mathrm{~h}$ ) was probably biotically mediated (Chambers et al. 1995). Work by Wolaver \& Spurrier (1988) showed that both salinity and water temperature were equally effective at explaining the flux of SRP in Bly Creek.
Changes in water and soil temperature can drastically alter microbial respiration in wetlands (Abdollahi \& Nedwell 1979, Gordon et al. 1986, Mazda et al. 1990), leading to changes in soil $\mathrm{pH}$ and redox potential (Eh). These changes affect concentration gradients between sediment and water column, thus regulating diffusive fluxes (DeLaune et al. 1981). Fluctuations in salinity can also regulate the flux of materials through a sequence of biotic and abiotic processes. Variation in salinity has been shown to affect the decomposition rate of mangrove leaves (Steinke et al. 1993, Davis 1999), the rate of phosphorus release from estuarine sediments (Clavero et al. 1990, Chambers et al. 1995) and the flocculation/sedimentation of phosphorus with various organic and inorganic particles (Sholkovitz 1976, Forsgren et al. 1996). Therefore, the flux relationships we observed in the dwarf mangrove likely reflect a complex interaction of chemical, physical, and biological processes that are driven by changes in temperature and salinity.

Of all the variables we considered, nutrient concentrations were the most powerful at predicting the flux of materials, especially for nitrogen. Total phosphorus uptake in the dwarf forest occurred as TP availability increased. Davis et al. (2001a) were unable to measure consistent fluxes of SRP. However, we assume SRP was also taken up by the wetland as it became available. Dissolved inorganic nitrogen uptake in the fringe wetland increased as water column $\left[\mathrm{NO}_{\mathrm{x}}^{-}\right]$and $\left[\mathrm{NH}_{4}{ }^{+}\right]$increased beyond about 0.9 and $3.5 \mu \mathrm{M}$, respectively. Whiting et al. (1989) observed the same relationships between DIN flux and concentration in Bly Creek. In addition, the approximated I/E switches for these constituents in Bly Creek were similar to ours at about $0.5 \mu \mathrm{M}$ for $\mathrm{NO}_{\mathrm{x}}{ }^{-}$ and approximately $3 \mu \mathrm{M}$ for $\mathrm{NH}_{4}{ }^{+}$(Whiting et al. 1989). The flux of $\mathrm{NO}_{\mathrm{x}}^{-}$in the dwarf mangrove wetland was more related to $\left[\mathrm{NH}_{4}{ }^{+}\right]$, reflecting the nitrification signal observed by Davis et al. (2001a).

The concentration/flux relationships we found suggest that either: (1) uptake increases as materials become available-as was exhibited by TN, TP (dwarf) $\mathrm{NO}_{\mathrm{x}}^{-}$, and $\mathrm{NH}_{4}{ }^{+}$(fringe); or (2) transformation increases as reactants become available-as was exhibited by the relationship between $\left[\mathrm{NH}_{4}{ }^{+}\right]$and $\mathrm{NO}_{\mathrm{x}}^{-}$(dwarf). Diffusive gradients are often important in driving wetland-water column fluxes. However, $\mathrm{NO}_{\mathrm{x}}{ }^{-}$export in the dwarf mangrove occurred in the absence of such a gradient, as porewater concentrations in the lower Taylor Slough often match water column concentrations (Oehm 1998). The opposite relationships exhibited by $\mathrm{NO}_{\mathrm{x}}^{-}$flux and concentration at each site might reflect a difference in the way in which these systems process nitrogen. Flux data support this, as $\mathrm{NO}_{\mathrm{x}}^{-}$was mainly released by the dwarf system and taken up by the fringe system (Davis et al. 2001a,b). 


\section{Applying monitoring data to flux relationships}

Using $1.5 \mathrm{yr}$ of continuous water quality data collected near our site, we estimated the daily flux of $\mathrm{N}$ and $\mathrm{P}$ in the dwarf mangrove wetland from significant regressions for TN (vs salinity and vs [TN]) and TP (vs concentration). Based on I/E switches and $95 \%$ confidence intervals calculated for each relationship, TN was imported by the dwarf mangrove wetland approximately $87 \pm 10 \%$ of the time, regardless of the inde-
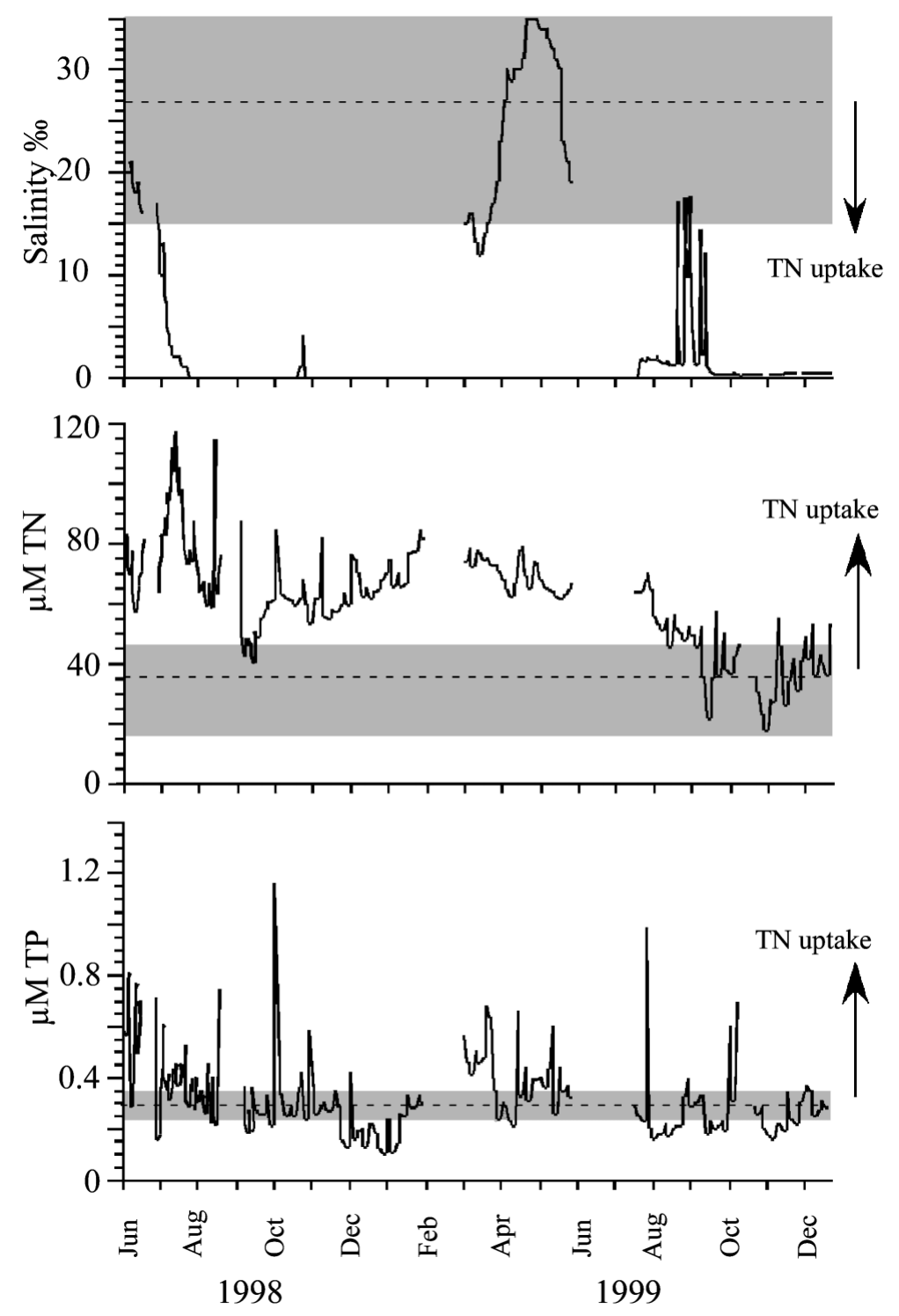

Fig. 6. Long-term salinity, concentrations of total nitrogen (TN), and total phosphorus (TP) data collected in the dwarf mangrove zone of the upper Taylor River from June 1998 through December 1999. Dashed lines illustrate import/export (I/E) switches predicted from regression relationships established for TN and TP flux. Shaded areas indicate $95 \%$ confidence intervals for the I/E switch of each regression and arrows indicate direction in which nutrient uptake was predicted to have occurred in the dwarf mangrove wetland pendent variable (salinity or $[\mathrm{TN}]$; Fig. 6). However, the predicted periods for export were quite different between salinity and [TN]. The time interval for TN export predicted using salinity was between April and June 1999-the transition between the dry and wet season. However, TN export predicted from [TN] occurred later in the wet season of 1999 (Fig. 6). It is worth noting that the relationship of TN flux with [TN] $\left(\mathrm{p}=0.008 ; \mathrm{r}^{2}=0.35\right)$ was somewhat stronger than it was with salinity $\left(\mathrm{p}=0.015 ; \mathrm{r}^{2}=0.3\right.$; Table 3$)$. The I/E switch for both of these relationships was nearly 2 standard deviations from the water quality means during this time frame $(6.5 \pm 10.7 \%$; $60.8 \pm 16.6 \mu \mathrm{M} \mathrm{TN}$; Table 3), indicating the infrequency of values at or beyond these thresholds in the dwarf mangrove wetland.

Predictions of TP flux revealed import by the dwarf wetland only $48 \pm 17 \%$ of the time, as concentrations were less than $0.3 \mu \mathrm{M}$ nearly as often as they were above this I/E switch (Fig. 6). In fact, the mean TP concentration $(0.33 \mu \mathrm{M})$ from June 1998 to December 1999 was nearly identical to the estimated I/E switch $(0.3 \mu \mathrm{M})$ for the dwarf mangrove wetland. This suggests that this particular wetland may be balanced in terms of total phosphorus exchange, and any increase or decrease in water column concentrations of TP in the dwarf mangrove may act to offset this balance. However, further intensive evaluation of the factors controlling the availability and fluxes of both of these constituents needs to be done in order to draw more reliable conclusions for the mangrove wetlands of the southern Everglades.

\section{SUMMARY}

We identified a number of factors that were useful in explaining the variability observed in the concentrations and fluxes of materials in the Taylor River mangrove wetlands. Season and water source were effective at explaining concentrations at both sites, especially for TOC, DOC, TN, and TP. With the exception of TP, these constituents were all likely derived from the same upland source. Dissolved inorganic nutrients, on the other hand, appeared to be derived via in situ transformation processes or from Florida Bay. Fluxes of materials, especially nitrogen species, were explainable by water temperature, salinity, and nutrient concentrations. However, calculated $\mathrm{r}^{2}$ values for these relationships were often weak, suggesting these factors alone do not account for the fluxes of 
materials we measured. Instead, they likely act in concert with other physical, chemical or biological factors to shape nutrient flux patterns in estuarine wetlands such those we considered.

Our findings indicate that the processes controlling nutrient and organic matter dynamics in the southern Everglades mangrove zone are sensitive to the regular, intra-annual variability in the factors we considered. Thus, we would expect these same processes to be sensitive to long-term alterations in freshwater delivery as a result of Everglades restoration. Freshwater flow through these estuarine wetlands into northeast Florida Bay is expected to increase with the advancement of Everglades restoration. The immediate effects of restoration will likely be changes in intra- and interannual water quality (salinity, nutrients, etc.) patterns. We expect these changes will affect ecological processing of materials in these estuarine wetlands, possibly leading to changes in wetland-water column exchanges as well as exchanges with adjacent systems (e.g. FW Everglades and Florida Bay).

Acknowledgements. We would like to acknowledge numerous individuals for providing input into this research and data analysis, especially J. Fourqurean, R. Jaffé, and R. Jones. We would also like to thank the Wetland Ecosystems Lab at Florida International University, 2 anonymous reviewers, and $\mathrm{K}$. Heck for providing helpful comments on earlier versions of this manuscript. The South Florida Water Management District provided funding for all research presented. This material is based upon ongoing work in the Florida Coastal Everglades Long-Term Ecological Research (FCE-LTER) Program and supported by the National Science Foundation under Grant \#9910514. This manuscript is SERC contribution \#196.

\section{LITERATURE CITED}

Abdollahi H, Nedwell D (1979) Seasonal Temperature as a factor influencing bacterial sulfate reduction in a saltmarsh sediment. Microb Ecol 5:73-79

Alongi DM (1988) Bacterial productivity and microbial biomass in tropical mangrove sediments. Microb Ecol 15: $59-79$

Alongi DM, Sasekumar A (1992) Benthic communities. In: Robertson AI, Alongi DM (eds) Tropical mangrove ecosystems. American Geophysical Union, Washington, DC, p 137-171

Ball MC (1988) Ecophysiology of mangroves. Trees 2:129-142

Boto KG (1982) Nutrient and organic fluxes in mangroves. In: Clough BF (ed) Mangrove ecosystems in Australia: structure, function and management. Australian National University Press, Canberra, p 240-257

Boto KG, Wellington JT (1988) Seasonal variations in concentrations and fluxes of dissolved organic materials in a tropical, tidally-dominated, mangrove waterway. Mar Ecol Prog Ser 50:151-160

Boynton WR, Kemp WM (1985) Nutrient regeneration and oxygen consumption by sediments along an estuarine salinity gradient. Mar Ecol Prog Ser 23:45-55

Chambers RM, Fourqurean JW, Hollibaugh JT, Vink SM
(1995) Importance of terrestrially-derived, particulate phosphorus dynamics in a west coast estuary. Estuaries 18(3):518-526

Childers DL, Cofer-Shabica S, Nakashima L (1993) Spatial and temporal variability in marsh-water column interactions in a southeastern USA salt marsh estuary. Mar Ecol Prog Ser 95:25-38

Cintrón G, Lugo AE, Pool DJ, Morris G (1978) Mangroves of arid environments in Puerto Rico and adjacent islands. Biotropica 10(2):110-121

Clavero V, Fernandez JA, Niell FX (1990) Influence of salinity on the concentration and rate of interchange of dissolved phosphate between water and sediment in Fuente Piedra lagoon (S Spain). Hydrobiologia 197:91-97

Clough BF (1992) Primary productivity and growth of mangrove forests. In: Robertson AI, Alongi DM (eds) Tropical mangrove ecosystems. American Geophysical Union, Washington, DC, p 225-250

Coronado-Molina C (2000) Litterfall dynamics and nutrient cycling in mangrove forests of Southern Everglades, Florida and Terminos Lagoon, Mexico. PhD thesis, Louisiana State University, Baton Rouge

Davis SE (1999) The exchange of carbon, nitrogen, and phosphorus in dwarf and fringe mangroves of the oligotrophic southern Everglades. PhD thesis, Florida International University, Miami

Davis SE, Childers DL, Day JW, Rudnick DT, Sklar FH (2001a) Carbon, nitrogen and phosphorus dynamics in a non-tidal dwarf mangrove wetland of the southern Everglades, Florida, USA. Estuaries 24(4):610-622

Davis SE, Childers DL, Day JW, Rudnick DT, Sklar FH (2001b) Nutrient dynamics in vegetated and unvegetated areas of a southern Everglades mangrove creek. Estuar Coast Shelf Sci 52:753-765

DeLaune RD, Reddy CN, Patrick WH Jr (1981) Effect of pH and redox potential on concentration of dissolved nutrients in estuarine sediment. J Environ Qual 10(3)276-278

Duke NC (1992) Mangrove floristics and biogeography. In: Robertson AI, Alongi DM (eds) Tropical mangrove ecosystems. American Geophysical Union, Washington, DC, p 63-100

Forsgren G, Jansson M, Nilsson P (1996) Aggregation and sedimentation of iron, phosphorus and organic carbon in experimental mixtures of freshwater and estuarine water. Estuar Coast Shelf Sci 43:259-268

Gordon AS, Cooper WJ, Scheidt DJ (1986) Denitrification in marl and peat sediments in the Florida Everglades. Appl Environ Microbiol 52(5)987-991

Guerrero GR, Cervantes DR, Jimenez IA (1988) Nutrient variation during a tidal cycle at the mouth of a coastal lagoon in the northwest of Mexico. Indian J Mar Sci 17:235-237

Kuenzler EJ (1974) Mangrove swamp systems. In: Odum HT, Copeland BJ, McMahon EA (eds) Coastal ecological systems of the United States, I. The Conservation Foundation, Washington, DC, p 346-371

Lee SY (1995) Mangrove outwelling: a review. Hydrobiologia. 295:203-212

Liebezeit G (1985) Sources and sinks of organic and inorganic nutrients in mangrove ecosystems. In: Cragg S, Polunin N (eds) Workshop on Mangrove Ecosystems Dynamics, I. UNDP/UNESCO, Port Moresby, p 167-170

Lugo AE, Snedaker SC (1974) The ecology of mangroves. Annu Rev Ecol Syst 5:39-64

Mazda Y, Sato Y, Sawamoto S, Yokochi H, Wolanski E (1990) Links between physical, chemical and biological processes in Bashita-minato, a mangrove swamp in Japan. Estuar Coast Shelf Sci 31:817-833 
McMillan C, Sherrod CL (1986) The chilling tolerance of black mangrove, Avicennia germainans, from the Gulf of Mexico Coast of Texas, Louisiana and Florida. Contrib Mar Sci 29:9-16

Odum WE, Fisher JS, Pickral JC (1979) Factors controlling the flux of particulate organic carbon from estuarine wetlands. In: Livingstone RJ (ed) Ecological processes in coastal and marine systems. Plenum Press, New York, p 69-80

Odum WE, McIvor CC, Smith TJ III (1982) The ecology of mangroves of south Florida: a community profile. US Fish and Wildlife Service, FWS/OBS-87/17, Washington, DC

Oehm NJ (1998) The effects of nutrient limitation and salinity on soil carbon mineralization rates in a carbonate-based mangrove ecosystem. MSc thesis, Florida International University, Miami

Ohowa BO, Mwashote BM, Shimbira WS (1997) Dissolved inorganic nutrient fluxes from two seasonal rivers into Gazi Bay, Kenya. Estuar Coast Shelf Sci 45:189-195

Ovalle ARC, Rezende CE, Lacerda LD, Silva CAR (1990) Factors affecting the hydrochemistry of a mangrove tidal creek, Sepetiba Bay, Brazil. Estuar Coast Shelf Sci 31: $639-650$

Rivera-Monroy VH, Day JW, Twilley RR, Vera-Herrera F, Coronado-Molina C (1995) Flux of nitrogen and sediments in Terminos Lagoon, Mexico. Estuar Coast Shelf Sci 40: 139-160

Sholkovitz ER (1976) Flocculation of dissolved organic and

Editorial responsibility: Kenneth Heck (Contributing Editor), Dauphin Island, Alabama, USA inorganic matter during the mixing of river water and seawater. Geochim Cosmochim Acta 40:831-845

Solorzano L, Sharp JH (1980) Determination of total dissolved phosphorus and particulate phosphorus in natural waters. Limnol Oceanogr 25(4):754-758

Steinke TD, Holland AJ, Singh Y (1993) Leaching losses during decomposition of mangrove leaf litter. S Afr J Bot 59(1):21-25

Sutula M (1999) Processes controlling nutrient transport in the southeastern Everglades wetlands, Florida, USA. PhD thesis, Louisiana State University, Baton Rouge

Twilley RR (1985) The exchange of organic carbon in basin mangrove forests in a southwest Florida estuary. Estuar Coast Shelf Sci 20:543-557

Whiting GJ, McKellar HN Jr, Spurrier JD, Wolaver TJ (1989) Nitrogen exchange between a portion of vegetated salt marsh and the adjoining creek. Limnol Oceanogr 34(2): 463-473

Wolaver TG, Spurrier JD (1988) The exchange of phosphorus between a euhaline vegetated marsh and the adjacent tidal creek. Estuar Coast Shelf Sci 26:203-214

Wolaver TG, Zieman JC, Wetzel R, Webb KL (1983) Tidal exchange of nitrogen and phosphorus between a mesohaline vegetated marsh and the surrounding estuary in the lower Chesapeake Bay. Estuar Coast Shelf Sci 16:321-332

Wolaver TG, Whiting GJ, Dame RF, Williams TM, Spurrier JD (1988) Bly Creek ecosystem study — nitrogen exchange within a euhaline salt marsh basin of North Inlet, South Carolina. Mar Ecol Prog Ser 49:107-116

Submitted: September 21, 2001; Accepted: December 12, 2002 Proofs received from author(s): March 27, 2003 